\title{
Collaboration in a wider Europe
}

Europe is in a mood to collaborate in research, as in much else, but doubts persist about the proper framework. This survey of science in Europe may resolve some issues.

EVERYBODY agrees that Europe is in transition, but the end-point is undefined. That is the starting point for the survey of science in Europe that occupies the following pages. Several important influences, cultural, economic and political, have conspired to provide an impetus for change that, in the long run, will help determine what the world is like, but the most interesting of them is the growing inclination of those who live in Europe to regard themselves as members of a community whose common interests transcend the chauvinistic differences that have bitterly divided them in the past.

That is why this survey differs markedly from others in this biannual eight-year series. It is not so much a record of achievement and disappointment in research, as of the mechanisms by which Europeans collaborate. And because there is so much going on, this will seem even more neglectful than previous surveys of important institutions contributing to the increasing cohesion of European science. It is hoped that those who are concerned with these institutions will not be too deeply offended.

Many of the institutions that now exist to foster European collaboration have their roots in the period immediately after the Second World War, and in the then common revulsion against the folly that had brought most European states economically to their knees. But there is an important sense in which the lesson also derives from the earlier 1914-18 war. In the settlement of that disaster, states called great powers redrew the map of Europe artificially while demanding that Germany should pay for the cost of the trouble it had caused - in retrospect a device for creating the conditions that made the Third Reich possible. That seemed a bad precedent in 1945. But by then, the great powers of the time had already (at Yalta) redrawn the European map so as to divide East from West. All the more necessary that the other ingredients of the settlement after 1918 should be avoided.

That is why the past 40 years have seen so many attempts in Western Europe to create a framework in which national interests and cultural differences would be subsumed within a common purpose. In rapid succession, there were formed the Western European Union (concerned with mutual defence), the Council of Europe (to foster common social and legal standards) and the succession of economic communities, which were at first concerned with commodities such as iron, steel and nuclear energy, but now, as with the twelve-member EEC, are concerned with the whole of economic activity. (The second half of this survey, beginning on page 726 , deals with EEC science and what should be done about it.)

Collaboration is evidently infectious. The dramatic proof of that is Mr Mikhail Gorbachev's recent talk of the "common European home". Gorbachev, who is not naïve, no doubt has many objectives. But suddenly, it seems, everyone wishes to collaborate. Poland, Hungary and Yugoslavia are talking of full membership of the Council of Europe, its Convention on Human Rights apparently not an obstacle. Turkey has applied for membership of the EEC, Austria is wondering whether to do so, while the Scandinavian countries and Switzerland may yet have a close relationship with the EEC.

Where will it end? And will the outcome revitalize European science? The continent (including its offshore islands) has never been full of optimists, which is why there is also now as great a need of realism. It is easier to decree collaboration than to ensure that it succeeds, especially in the practice of scholarship and research and when the decrees are made by politicians. Here are some challenges and rules for optimists:

- Higher education. In the 1860s, the great Ernst Mach left Vienna to teach at Prague, which is not very far away, but that would not now seem a natural move. Europe now has too many separate university systems. Even within the EEC, too many universities are too tightly in the pockets of their governments, national or even regional, yet there are no plans for integrating them. So how, and when, to make progress towards a wider framework?

- Basic research. There are two frameworks of collaboration - within the EEC, and more extensive (typified by CERN and the European Science Foundation). Within the EEC, the European Commission should in future play a stronger part in supporting basic research (see page 734), but that may be detrimental to wider collaboration. How are those desirable goals to be balanced?

Applied research. The EEC centrally supports research intended to put its industry in better shape, but there are contradictions, not least that with the principle that successful industrial companies stand on their own feet, paying for their own research and development. EEC practice is also a potential impediment to wider economic collaboration. How will those issues be resolved?

In all this, there is a crucial issue too often overlooked - the danger that European collaboration in some defined framework will be exclusive of the world outside. The danger that the EEC will emerge from the upheaval planned for 1992 as a high-tariff chauvinistic group of selfsatisfied states is the most immediate. Those who would suffer most would be those stranded within the tariff barriers, but Europe's relationship with the outside world would also be seriously damaged. That is why the EEC's goal of a single market, promised for 1992, is not in itself sufficient. It also matters crucially whether it is an outgoing grouping. 